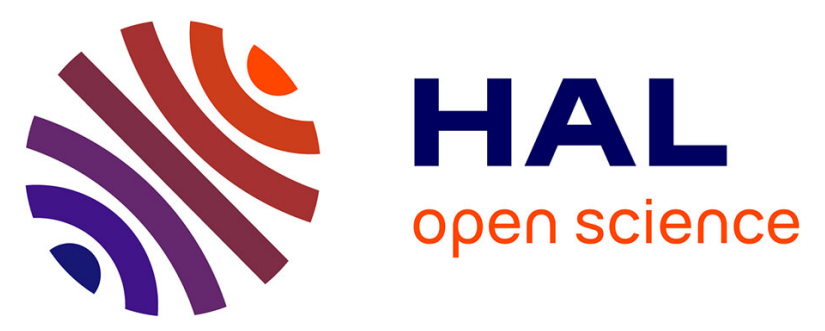

\title{
Efficacy of five alcohol-based skin antiseptics on sebaceous skin used at shorter application times than the current recommendation of 10 minutes
}

N.-O. Hübner, O. Assadian, S. A. Grohmann, M. Diab-Elschahawi, A. Kramer

\section{- To cite this version:}

N.-O. Hübner, O. Assadian, S. A. Grohmann, M. Diab-Elschahawi, A. Kramer. Efficacy of five alcohol-based skin antiseptics on sebaceous skin used at shorter application times than the current recommendation of 10 minutes. European Journal of Clinical Microbiology and Infectious Diseases, 2011, 30 (7), pp.825-829. 10.1007/s10096-010-1085-x . hal-00700807

\section{HAL Id: hal-00700807 \\ https://hal.science/hal-00700807}

Submitted on 24 May 2012

HAL is a multi-disciplinary open access archive for the deposit and dissemination of scientific research documents, whether they are published or not. The documents may come from teaching and research institutions in France or abroad, or from public or private research centers.
L'archive ouverte pluridisciplinaire HAL, est destinée au dépôt et à la diffusion de documents scientifiques de niveau recherche, publiés ou non, émanant des établissements d'enseignement et de recherche français ou étrangers, des laboratoires publics ou privés. 
Efficacy of five alcohol-based skin antiseptics on sebaceous skin used at shorter application times than the current recommendation of 10 minutes

Short title: Shorter application time for sebaceous skin antisepsis.

Hübner Nils-Olaf ${ }^{\text {a }}$, Assadian Ojan ${ }^{\text {a,* }}$, Grohmann Steffen Andreas ${ }^{\text {b }}$, Diab-Elschahawi Magda

${ }^{\mathrm{c}}$, Kramer Axel $^{\mathrm{a}}$

a Institute for Hygiene and Environmental Medicine, Ernst-Moritz-Arndt University Greifswald, Germany

${ }^{\mathrm{b}}$ Department of Orthopaedic Surgery, Ernst-Moritz-Arndt University Greifswald, Germany

${ }^{\mathrm{c}}$ Department of Hospital Hygiene, Medical University of Vienna, Austria

\section{Corresponding author:}

Prof. Dr. Ojan Assadian, DTMH (Lond.)

Institute for Hygiene and Environmental Medicine

Ernst-Moritz-Arndt University Greifswald

Walther-Rathenau-Straße 49A

17489 Greifswald, Germany

Tel.: +49-3834-515542; Fax: +49-3834-515541

E-mail: assadian@uni-greifswald.de 


\section{Summary}

Purpose: Alcohol-based skin antiseptics are recommended with a minimum application time of 10 minutes on skin containing high numbers of sebaceous glands. In clinical practice, a 10 minute application time often is too long. Therefore, we determined the efficacy of skin antiseptics on the forehead and lower back using shorter application times. Methods: Five alcoholic solutions were tested in a double-blind trial for their cfu reduction after 3, 4, 5, and 10 minutes on forehead of 20 healthy volunteers and lower back of 10 healthy volunteers and 10 patients against the reference alcohol $70 \%$ propan-2-ol, 10 min. Results: After an application time of 3 minutes, 3/5 (forehead) and 5/5 preparations (lower back) were at least equally effective as compared to the reference alcohol and an application time of 10 minutes. Conclusion: Alcohol-based skin antiseptics do not require 10 min application time. For all of the tested antiseptics a minimum application time of 3 minutes on sebaceous skin can be recommended.

Key words: skin antisepsis; sebaceous skin; application time; alcohol-based antiseptics; 


\section{Introduction}

Currently, in Germany and Austria all alcohol-based skin antiseptics are recommended with a minimum application time of 10 minutes on skin areas containing high numbers of sebaceous glands. ${ }^{1}$ Because currently there is no European Norm available to determine the efficacy of preparations for skin antisepsis, in Germany and Austria the efficacy of a preparation is commonly determined according to the test method of the German Society for Hygiene and Microbiology. ${ }^{2}$ This test method requires $70 \% \mathrm{v} / \mathrm{v}$ iso-propanol during an application time of 10 minutes on skin with a high density of sebaceous glands. This leads to the requirement that the antimicrobial efficacy of any new skin antiseptic must not be significantly above the efficacy of the reference antisepsis with iso-propanol (70\%, v/v) for 10 minutes. $^{1,3}$

In clinical practice, however, a 10 minute application time often is far too long, especially in emergency situations or in settings with high patient volumes, and it makes compliance to the manufacturers' recommendation difficult. As the work leading to the recommendation is 20 years old and it is based on the application of $70 \% \mathrm{v} / \mathrm{v}$ iso-propanol alone, it seems necessary to re-evaluate the recommendation, as new products containing combinations of different alcohols are available now. Recently published data on surgical hand disinfection ${ }^{4,5}$ reviled that for certain propanol-based preparations a shorter application time than the previously recommended 3 minutes is achievable with the same effect on the resident hand flora. The results for surgical hand disinfection support new studies for skin antisepsis, as for particular preparations the application time also might be shorter than 10 minutes. In deed, two skin antiseptics based on $85 \%$ ethanol were described recently having an equivalent efficacy on the forehead of healthy volunteers within an application time of only 2.5 minutes. ${ }^{6}$ The efficacy on the bacterial flora of patients using shorter application times and on other anatomic skin sites containing high numbers of sebaceous glands has not been published so far. Therefore, the aim of our study was to determine the efficacy of five alcohol-based skin antiseptics on the bacterial flora of the forehead (only volunteers) and lower back (volunteers and patients). 


\section{Methods}

\section{Design and preparation of subjects}

Each experiment was performed in a double-blind reference-controlled cross-over design. ${ }^{2} \mathrm{~A}$ minimum of 20 volunteers was recruited per experiment. Only participants with healthy skin on the forehead and the lower back were selected (no injury, eczema or other inflammatory skin disease). Subjects were excluded when they took antibiotics or had previously used a disinfectant or antiseptic solution within the last seven days before any experiment. Bathing and showering was not allowed $24 \mathrm{~h}$ prior to an experiment. Hair around the test site was clipped or tied back in order to prevent recontamination of the skin of the forehead during the experiments. The inclusion and exclusion criteria were applied to both, 20 healthy volunteers in the forehead group and 10 healthy volunteers and 10 patients in the lower back group. The skin on the forehead and the lower back was divided into five areas of approximately five $\mathrm{cm}^{2}$ next to each other. The left area was always chosen to determine the baseline bacterial density. The other test fields were allocated from the left side to right side: 3 min post-value, 4 min post-value, 5 min post-value, 10 min reference treatment post value. A cotton swab was soaked with the tested skin antiseptic and was swabbed strictly over the marked test field. The procedure was repeated as many times as necessary to keep the skin moist with the skin antiseptic for the examined application time.

\section{Products and application}

The following preparations were tested: R) propan-2-ol (70\%, v/v) as reference alcohol; A) Manorapid synergy, a hand and skin antiseptic based on 57.6\% (w/w) ethanol (96\%) and 10\% (w/w) 1-propanol (Antiseptica GmbH, Pulheim, Germany); B) Skin-Des (Polyalcohol Hautantiseptikum), a skin antiseptic based on 63.1\% [w/w] 2-propanol (Antiseptica GmbH, Pulheim, Germany); C) Cutasept F, a skin antiseptic based on 63\% (w/w) 2-propanol (Bode Chemie GmbH \& Co. KG, Hamburg, Germany); D) VP 365, an alcohol-based antiseptic 
containing 85\% (w/w) ethanol (Bode Chemie GmbH \& Co. KG, Hamburg, Germany); and E) VP 505, an alcohol-based solution containing 65\% (w/w) 2-propanol and $0.2 \%(\mathrm{w} / \mathrm{w})$ mecetronium etilsulphate (Bode Chemie GmbH \& Co. KG, Hamburg, Germany).

All preparations were colourless and blinded to participants and laboratory staff. All skin antiseptics were tested for application times of 10 minutes, 5 minutes, 4 minutes, and 3 minutes (forehead and lower back). The reference alcohol was always applied for 10 minutes to the skin of the forehead according to the recommended test method. ${ }^{2}$

\section{Antiseptic phase}

One marked skin area was treated with the reference alcohol, three other areas with one of the antiseptic products each. After each skin antisepsis a sample was taken (post-value) immediately after completion of the application $(10,5,4$ or 3 minutes after beginning of the application). Between each application of the product, a resting period of at least one week elapsed in order to allow complete reconstitution of the normal skin flora.

\section{Determination of the pre-values and post-values}

Sampling and cultivation were done according to the test method of the German Society for Hygiene and Microbiology. ${ }^{2}$ Each sampling area was marked in such a way that the standard size of $5 \mathrm{~cm}^{2}$ was clearly visible. A cotton swab was soaked in tryptic soy broth (TSB). The sampling area was rigorously rubbed as described before. ${ }^{7}$ Meticulous care was taken to ensure that the swab was only rubbed within the marked skin area. Then, the swab was transferred into $5 \mathrm{ml}$ of TSB containing a combination of neutralizing agents for inactivation of residual microbiocidal activity. The following neutralizing agents were used: $3 \%$ Tween $80,3 \%$ saponine, $0.1 \%$ histidine and $0.1 \%$ cysteine. The combination of neutralizing agents was previously found to be valid for neutralization of $85 \%$ ethanol. The tube was vortexed for 
$30 \mathrm{sec}$ at high frequency. A serial dilution was done in TSB. From appropriate dilution steps, aliquots of $1 \mathrm{ml}$ were spread on tryptic soy agar (TSA) in duplicate.

\section{Calculation of bacterial reduction}

The plates were incubated for a total of $48 \mathrm{~h}$ at $36^{\circ} \mathrm{C}$, and the colony-forming units (cfu) from plates were counted. For calculation purposes, plate count values $\leq 300$ cfu were accepted. Plate count values of zero were reset to 1 , as the $\log 10$ of 0 is undefined, but the $\log 10$ of $1=$ zero. The weighted mean of cfu was calculated taking into account the number of cfu per plate and the corresponding dilution step. The weighted mean was multiplied by the dilution factor in order to obtain the number of cfu per $\mathrm{ml}$ in the sampling liquid. All pre- and postvalues were expressed as $\log 10$ values. For each experiment, the logarithmic reduction factor $(\log 10 \mathrm{RF})$ was calculated as the difference between the $\log 10$ baseline value and the $\log 10$ post-values.

\section{Statistics}

A comparison of multiple mean log 10 RFs was done using Friedman's ANOVA. In addition, based on the DGHM test method for skin antisepsis a product is considered effective for skin antisepsis if the mean is not significantly lower than the corresponding mean $\log 10 \mathrm{RF}$ of the 10 min reference treatment (one sided Wilcoxon matched-pairs signed-ranks test). Differences of all other means were investigated by the two sided Wilcoxon matched-pairs signed-ranks test. $^{2}$ A P-value $<0.05$ was chosen to indicate a significant difference. 


\section{Results}

Skin antisepsis on the forehead

Product A was most effective after 5 min and less effective after 4 and 3 min (Table I). The difference between all four treatments was significant $(\mathrm{P}=0.007$; Friedman's ANOVA). A pair-wise analysis did not reveal a statistically significant difference in the efficacy between any of the application times of product $\mathrm{A}$ in comparison to the reference treatment $(\mathrm{P}>0.05$; two sided Wilcoxon matched-pairs signed-ranks test).

Product B was also most effective after 5 min and less effective after 4 and 3 min (Table I). The difference between all four treatments was significant $(\mathrm{P}<0.001$; Friedman's ANOVA). A pair-wise analysis revealed a significant lower efficacy for any of the application times of product $\mathrm{B}$ in comparison to the reference treatment $(\mathrm{P}<0.005$; one sided Wilcoxon matchedpairs signed-ranks test).

Product $\mathrm{C}$ also showed the highest efficacy after $5 \mathrm{~min}$ and a lower efficacy after 4 and 3 min (Table I). The difference between all four treatments was significant $(\mathrm{P}<0.001$; Friedman's ANOVA). A pair-wise analysis revealed only a significant lower efficacy for a $3 \mathrm{~min}$ application time of product $\mathrm{C}$ in comparison to the reference treatment $(\mathrm{P}=0.001$; one sided Wilcoxon matched-pairs signed-ranks test).

Product D showed also the best efficacy after $5 \mathrm{~min}$ and a lower efficacy after 4 and 3 min (Table I). The difference between all four treatments was significant $(\mathrm{P}<0.019$; Friedman's ANOVA). An application time of 5 min was significantly more effective in comparison to the reference treatment $(\mathrm{P}=0.023$; two-sided Wilcoxon matched-pairs signed-ranks test). For the other exposure times the efficacy was equal to the reference.

Product E showed the best efficacy after $5 \mathrm{~min}$ and a lower efficacy after 4 and $3 \mathrm{~min}$ (Table I). The difference between all four treatments was not significant $(\mathrm{P}<0.218$; Friedman's ANOVA). 
Product $\mathrm{A}$, product $\mathrm{B}$, product $\mathrm{C}$, and product $\mathrm{D}$ were equally effective as compared to the reference treatment (Table II). The difference between all four treatments each were not significant $(\mathrm{P}=0.735 ; \mathrm{P}=0.902 ; \mathrm{P}=0.531 ; \mathrm{P}=0.715 ;$ Friedman's ANOVA $)$, respectively. Product E was also equally effective in comparison to the reference treatment (Table II). The difference between all four treatments, however, was significant $(\mathrm{P}=0.009$; Friedman's ANOVA). A pair-wise comparison between product $\mathrm{E}$ and the reference treatment revealed no significant difference for any of the application times $(\mathrm{P}>0.05$; one sided Wilcoxon matched-pairs signed-ranks test). No statistical difference was observed in pre- and post results for healthy volunteers and patients on the lower back $(\mathrm{P}>0.05$; two sided Wilcoxon matched-pairs signed-ranks test). 


\section{Discussion}

Based on our results it seems not to be necessary to insist on a standard 10 minute application time for skin antisepsis on the forehead or the lower back as it is currently required by the test method of the German Society for Hygiene and Microbiology. ${ }^{8}$ Our data revealed a strong difference between the efficacy of skin antiseptics on forehead and lower back. On the lower back, all tested skin antiseptics were as effective as the reference alcohol within 3 minutes, while on the forehead two of the five preparations were significantly less effective within 3 min, as compared to the reference alcohol. The reason for this finding is the different baseline bacterial density and probably the different density of the number of sebaceous glands per $\mathrm{cm}^{2}$ (2.1 vs. $\left.3.7 \log 10\right)$. Similar baseline values have been reported before..$^{9,10}$

Application of skin antiseptics for 4 minutes on the lower back of volunteering patients yielded a reduction of resident bacteria equivalent to the $10 \mathrm{~min}$ reference antisepsis. It is likely that even shorter application times might reveal an equivalent efficacy on the lower back, however, as we did not investigate shorted application times and therefore no proof, this remains speculation at this stage. Using product $\mathrm{D}$, for example, the bacterial $\log \log 10 \mathrm{RF}$ was 1.14 in healthy volunteers and 0.88 in volunteering patients (sub-group data not shown in table II). Particularly the ethanol-based skin antiseptics are likely to be effective even after shorter application times, as recent data show that on the forehead an application time of 2.5 min still was equally effective to the 10 min reference procedure. ${ }^{6}$

The efficacy of all antiseptics was lower on the lower back than on the forehead. This finding was expected as the mean baseline bacterial density was quite high with bacterial densities of $3.7 \log 10$ on the forehead and remarkably lower on the lower back with $2.1 \log 10$. Resident bacteria apparently can be reduced to a maximum level which can be described as the "irreducible minimum". Prolongation of the application time will not provide any increase of 
efficacy, which also was also recently shown, albeit for surgical hand disinfection., ${ }^{4,5}$

Of importance are our results showing that the mean efficacy of two skin antiseptics applied for 4 minutes on the lower back was equal for both, healthy volunteers and volunteering patients. Similar results between volunteers and patients have been described earlier by Kurth

et al. ${ }^{11}$ Testing the efficacy of skin antiseptics on healthy volunteers can therefore be considered to be a valid method for assuming an efficacy on patients' skin as well.

Since the baseline bacterial density and the resulting reduction factors between forehead and lower back differ, skin antiseptics should be tested on the anatomic sides for which a specific product is intended, and not on the forehead alone. Further research therefore should also include other skin sites such as the perineum, breast, joints and the foot.

\section{Conclusions}

Short application times are desirable for skin antisepsis to ensure maximum compliance and efficacy, even under emergency conditions. Application times for skin antiseptics on the forehead or the lower back should be based on their "true application time" or the time, when they are equally effective as compared to the reference skin antiseptic using propan-2-ol (70\%, v/v) for 10 minutes application time. Alcohol-based skin antiseptics do not require a standard 10 min application time, especially on the lower back. Most antiseptics surpass the mean $\log 10$ reduction factor of the reference alcohol within 10 minutes application time already after 3 or 4 min on the forehead and lower back, respectively. For all of the tested antiseptics a minimum application time of 3 minutes on skin containing sebaceous glands can be recommend. 


\section{List of abbreviations}

TSB

Trypton-Soya-Broth

TSA

Trypton-Soya-Agar

$\mathrm{cfu}$

Colony-Forming Units

$\log 10 \mathrm{RF}$

logarithmic Reduction Factor

\section{Competing Interests}

The study was sponsored by Bode Chemie GmbH \& Co. KG, Hamburg, Germany and Antiseptica chem.-pharm. Produkte GmbH, Pulheim/Brauweiler, Germany. The sponsors had no participation in the study design, analysis and interpretation of data. The authors declare no competing interests.

\section{Authors' contributions}

$\mathrm{NOH}, \mathrm{SAG}$ and AK designed the study, NOH, OA, MD and SAG analysed the data, OA, $\mathrm{NOH}, \mathrm{MD}$ and AK wrote the manuscript; All authors read and approved the final manuscript. 


\section{References}

[1] Christiansen B, Eggers HJ, Exner M, et al. (1991) Richtlinie für die Prüfung und Bewertung von Hautdesinfektionsmitteln. Zentralbl Hyg Umweltmedizin 192:99-103

[2] Gebel J, Werner H-P, Kirsch-Altena A, Bansemir K (2002) Standardmethoden der DGHM zur Prüfung chemischer Desinfektionsverfahren. Wiesbaden: mhp-Verlag

[3] Desinfektionsmittelkommission im Verbund für angewandte Hygiene e.V. (VAH) (2006). Desinfektionsmittelliste der VAH. Wiesbaden: mhp-Verlag

[4] Kampf G, Ostermeyer C, Heeg P (2005) Surgical hand disinfection with a propanol-based hand rub: equivalence of shorter application times. J Hosp Infect 59:304-310

[5] Rotter ML, Kampf G, Suchomel M, Kundi M (2007) Long-term effect of a 1.5 minute surgical hand rub with a propanol-based product on the resident hand flora. J Hosp Infect 66:84-85

[6] Kampf G, Pitten FA, Heeg P, Christiansen B (2007) Efficacy of two ethanol-based skin antiseptics on the forehead at shorter application times. BMC Microbiol 7:85

[7] Gundermann KO, Christiansen B, Höller C (1985) New methods for determining preoperative and postoperative skin disinfection. J Hosp Infect 6:S51-S57

[8] Desinfektionsmittel-Kommission der DGHM (2002) Anforderderungskatalog für die Aufnahme von chemischen Desinfektionsverfahren in die Desinfektionsmittel-Liste der DGHM. Wiesbaden: mhp-Verlag

[9] Henning DR, Griffin TB, Maibach HI (1975) Studies on changes in skin surface bacteria in induced miliaria and associated hypohydrosis. Acta Derm Venereol 52:371-375

[10] Somerville DA, Murphy CT (1973) Quantitation of Corynebacterium acnes on healthy human skin. J Invest Dermatol 60:231-233

[11] Kurth D, Christiansen B, Gundermann KO (1989) Vergleich der Wirksamkeit der Hautdesinfektion bei Gesunden und Krankenhauspatienten. Hyg Med 14:225-227 
Table I Mean $\log 10$-reduction of resident skin flora obtained with four skin antiseptics on the forehead of 20 healthy volunteers applied for 3, 4 and $5 \mathrm{~min}$ in comparison to a $10 \mathrm{~min}$ reference skin antisepsis.

\begin{tabular}{|l|l|l|l|l|}
\hline \multirow{2}{*}{ Test product } & \multicolumn{2}{l}{ Mean RF \pm standard deviation } \\
\cline { 2 - 5 } & Reference $(10 \mathrm{~min})$ & Preparation $(5 \mathrm{~min})$ & Preparation (4 min) & Preparation (3 min \\
\hline A $(\mathrm{n}=20)$ & $1.57 \pm 0.66$ & $2.05 \pm 0.59$ & $1.83 \pm 0.62$ & $1.57 \pm 0.46$ \\
\hline $\mathrm{B}(\mathrm{n}=20)$ & $2.47 \pm 0.53$ & $2.15 \pm 0.69$ & $1.93 \pm 0.67$ & $1.60 \pm 0.52$ \\
\hline $\mathrm{C}(\mathrm{n}=20)$ & $1.88 \pm 0.74$ & $2.05 \pm 0.63$ & $1.68 \pm 0.62$ & $1.48 \pm 0.58$ \\
\hline $\mathrm{D}(\mathrm{n}=20)$ & $1.67 \pm 0.75$ & $2.16 \pm 0.79$ & $1.82 \pm 0.70$ & $1.75 \pm 0.69$ \\
\hline $\mathrm{E}(\mathrm{n}=20)$ & $1.41 \pm 0.80$ & $1.92 \pm 0.82$ & $1.55 \pm 0.74$ & $1.59 \pm 0.95$ \\
\hline
\end{tabular}


Table II Mean log10-reduction of resident skin flora obtained with four skin antiseptics on the lower back of 10 healthy volunteers and 10 patients each, applied for 3, 4 and 5 min in comparison to a 10 min reference antisepsis.

\begin{tabular}{|c|c|c|c|c|c|}
\hline \multirow{2}{*}{$\begin{array}{l}\text { Test } \\
\text { product }\end{array}$} & \multicolumn{4}{|c|}{ Mean RF \pm standard deviation } & \multirow{2}{*}{$\begin{array}{l}\mathrm{P}- \\
\text { value }\end{array}$} \\
\hline & $\begin{array}{l}\text { Reference }(10 \\
\text { min) }\end{array}$ & $\begin{array}{l}\text { Preparation }(5 \\
\text { min) }\end{array}$ & $\begin{array}{l}\text { Preparation }(4 \\
\min )\end{array}$ & $\begin{array}{l}\text { Preparation }(3 \\
\text { min) }\end{array}$ & \\
\hline$A(n=20)$ & $1.24 \pm 0.32$ & $1.22 \pm 0.36$ & $1.24 \pm 0.32$ & $1.09 \pm 0.65$ & 0.735 \\
\hline$B(n=20)$ & $1.23 \pm 0.35$ & $1.20 \pm 0.36$ & $1.20 \pm 0.36$ & $1.22 \pm 0.35$ & 0.902 \\
\hline$C(n=20)$ & $0.99 \pm 0.47$ & $0.98 \pm 0.47$ & $0.95 \pm 0.40$ & $0.95 \pm 0.40$ & 0.531 \\
\hline $\mathrm{D}(\mathrm{n}=20)$ & $1.15 \pm 0.44$ & $1.11 \pm 0.40$ & $1.14 \pm 0.42$ & $1.00 \pm 0.55$ & 0.715 \\
\hline $\mathrm{E}(\mathrm{n}=20)$ & $1.14 \pm 0.44$ & $0.87 \pm 0.52$ & $0.95 \pm 0.44$ & $1.07 \pm 0.36$ & 0.009 \\
\hline
\end{tabular}

